\title{
Social Support, Common Mental Disorder and Abusive Use of Alcohol in Rural Settlements
}

\author{
João Paulo Macedo*, 1 \\ Orcid.org/0000-0003-4393-8501 \\ Magda Dimenstein ${ }^{2}$ \\ Orcid.org/ 0000-0002-5000-2915 \\ Brisana Índio do Brasil de Macêdo Silva ${ }^{1}$ \\ Orcid.org/0000-0003-1150-8291
}

Hédina Rodrigues de Sousa ${ }^{1}$

Orcid.org/0000-0002-6080-2828

Ana Paula Almeida da Costa ${ }^{1}$

Orcid.org/0000-0002-0490-7369

${ }^{1}$ Universidade Federal do Piauí, Teresina, PI, Brasil

${ }^{2}$ Universidade Federal do Rio Grande do Norte, Natal, RN, Brasil

\begin{abstract}
Rural Brazilian population suffers with several situations of vulnerability, living in poor life conditions and with difficult access to healthcare. This study aimed to investigate life conditions and forms of social support in rural settlements in Piauí, regarding cases of Common Mental Disorder (CMD) and abusive use of alcohol. Therefore, a cross sectional study was conducted in two settlements: Santo Antonio $(n=1,060)$ and Canárias $(n=432)$, totalising 1,492 participants. The instruments used were a socialdemographic questionnaire; the Self-Reporting Questionnaire (SRQ-20), the Alcohol Use Disorders Identification Test (AUDIT) and the Medical Outcomes Study (MOS). Among the participants who fitted the inclusion and exclusion criteria to participate in the study $(n=762)$, it was identified $160(21 \%)$ cases of CMD in the two settlements, with higher prevalence among women and people over 30 years old; and 89 (11.6\%) of risky consume, harmful use and alcohol dependency. Regarding social support, participants considered insufficient and not enough present in the daily life. The perception of fragility of support in the five evaluated dimensions (material, information, affective, emotional and positive social interaction) is associated with problems in the infrastructure, and in life conditions and it presents important differences between men and women.
\end{abstract}

Keywords: Social support, common mental disorders, alcohol, rural population.

Mailing address: Universidade Federal do Piauí, Campus Universitário Ministro Petrônio Portella, Bairro Ininga, Teresina, PI, Brazil. E-mail: jpmacedo@ufpi.edu.br, mgdimenstein@gmail.com, brisanaindio@gmail. com,hedina_sousa@hotmail.com and ana_almeidac@hotmail.com

Financing: Conselho Nacional de Desenvolvimento Científico e Tecnológico (CNPq). 


\section{Apoio Social, Transtorno Mental Comum e Uso Abusivo de Álcool em Assentamentos Rurais}

\section{Resumo}

A população rural brasileira sofre com inúmeras situações de vulnerabilidade, convive com precárias condições de vida e dificuldades de acesso à saúde. Objetivamos investigar as condições de vida e formas de apoio social em assentamentos de reforma agrária no Piauí frente aos casos de Transtorno Mental Comum (TMC) e de uso abusivo de álcool. Para isso, realizou-se um estudo de corte transversal em dois assentamentos: Santo Antônio $(n=1.060)$ e Canárias $(n=432)$, totalizando 1.492 participantes. Foram utilizados questionário sócio demográfico; Self-Reporting Questionnaire (SRQ-20), Alcohol Use Disorders Identification Test (AUDIT) e Escala Medical Outcomes Study(MOS). Dentre os participantes que atenderam aos critérios de inclusão/exclusão para aplicação dos instrumentos $(n=762)$, identificouse $160(21 \%)$ casos de TMC nos dois assentamentos, com maior prevalência entre as mulheres e em moradores acima de 30 anos; e $89(11,6 \%)$ casos com consumo de risco, uso nocivo e dependente de álcool. Quanto ao apoio social, os moradores o consideram insuficiente e pouco presente no dia a dia. A percepção de fragilidade de suporte nas cinco dimensões avaliadas (material, informação, afetivo, emocional e interação social positiva) está associada aos problemas de infraestrutura, de condições materiais de vida e apresenta diferenças importantes entre homens e mulheres.

Palavras-chave: Apoio social, transtornos mentais comuns, álcool, população rural.

\section{Apoyo social, Trastorno Mental Común y Uso Abusivo de Alcohol en los Asentamientos Rurales}

\section{Resumen}

La población rural brasileña sufre de numerosas situaciones de vulnerabilidad, precarias condiciones de vida y dificultades de acceso a la salud. Se objetivo investigar las condiciones de vida y formas de apoyo social en asentamientos de reforma agraria en Piauí frente a los casos de Trastorno Mental Común (TMC) y de uso abusivo de alcohol. Para tal se realizó un estudio de corte transversal en dos asentamientos: Santo Antônio $(n=1.060)$ y Canárias $(n=432)$, totalizando 1.492 participantes. Se utilizaron un cuestionario demográfico; el Self-Reporting Questionnaire (SRQ-20), el Alcohol Use Disorders Identification Test (AUDIT) y la Escala Medical Outcomes Study (MOS). Dentre los participantes que atenderon a los critérios de inclusión/exclusión para aplicación de los instrumentos $(n=762)$, se identificó $160(21 \%)$ casos de TMC en los dos asentamientos, con prevalencia entre las mujeres y en los residentes mayores de 30 años; y 89 (11,6\%) casos con consumo de riesgo, uso nocivo y dependente de alcohol. En cuanto al apoyo social, los residentes lo consideran insuficiente y poco presente en el cotidiano. La percepción de la fragilidad de suporte en las cinco dimensiones evaluadas (material, información, afectivo, emocional y interación social positiva) se asocia con los problemas de infraestructura, condiciones materiales de vida y presenta diferencias importantes entre hombres y mujeres.

Palabras clave: Apoyo social, trastornos mentales comunes, alcohol, población rural.

The Brazilian rural population has as a historical trait a complex landscape of inequalities and difficulties to access a wide range of public policies. Studies show that the precarious life conditions of the countryside populations favor the increase of morbidity and mortality of transmissible diseases, childhood mortality, epidemical incidence, and the development of chronicdegenerative diseases (Sparovek, 2003). On the other hand, the lack of infrastructure and the 
typical problems caused from the lack of social development, accompanied by the high levels of poverty and deprivation, precarious work and education conditions, bring damages to the mental health of rural populations, that despite being evident, are not approached by many studies on an national or international level (Dimenstein, Leite, Macedo, \& Dantas, 2016; Santana, 2015).

Rehm and Parry (2009), in a study made in a world-wide level, point to the fact that mental disorders and the abusive use of alcohol have a deeper negative impact in poorer populations, due to the vulnerable conditions they find themselves, and the few sanitary resources they can count on. The picture described by the authors above are emphasized when dealing with rural settlements in Brazil, due to their hardships through life, work, poverty, social isolation and the low reach of the public services that are available to them. Under this context, the rural population is more vulnerable to manifesting conditions that can lead to Average Mental Disorders (AMD) and aggravating abusive use of alcoholic beverages (Costa \& Ludermir, 2005; Silva, 2015).

In this sense it's possible to observe that health and well-being are conditioned to the places and life environments of populations, whether they are rural or urban. For Loureiro, Lima, Partidário, and Santana (2015), the characteristics of the territories where one is born, grows up in, lives in, works at and grows old are fundamental for the promotion of health and well-being, and can produce good or bad impact on mental health. Working with this assumption, the authors rank some of the characteristics that should be taken in consideration called "Contextual Conditionals of Mental Health" (p. 13), divided in three axis: physical and constructed environment (habitation, sanitation, pollution, transport, green spaces, environmental quality, population concentration, design and maintenance of the space, field use, access to equipment and services, safety); socio-economic environment (poverty, earnings, employment/unemployment, education, food safety) and social and cultural interaction (social networks and social support, social capital, social cohesion, identity, belong- ing and identity, racism and discrimination, justice). We then consider that social support (SS) constitutes an important protection factor and promotion of health.

Despite the many definitions and conceptions of what is social care, according to the literature, it's a multidimensional process that plays an important role in determining or mediating the levels of health and welfare of individuals, involving sociability practices and care produced in spaces such as family, friends, neighbours, groups, associations, social equipaments, institutions and etc. (Peña, 2005).

Countless studies that deal with social support point to its importance as an efficient factor in protecting and promoting health, involving physical aspects, emotional and psychoaffective in the lives of subjects, and is highlighted in the lives of those who suffer of chronic illness (Abreu-Rodrigues \& Seidl, 2013; Rodrigues, Ferreira, \& Caliri, 2013; Santos, 2015). This perception in support is referred to by Jussani, Serafim, and Marcon (2007) as primordial for the maintenance of the subjective well-being of people facing the most diverse situations of psychic suffering and psychiatric disturbances such as suicide, depression, anxiety problems, insomnia, handling stressing situations, alcohol and other drugs abstinence, treating illnesses such as cancer, child school socialization, reactions to hospital emergencies, pregnancy, old age, among others.

Rocha, Guimarães, and Cunha (2012) indicate that while social support might be an important maintenance factor in strengthening health and well-being, in less favored social classes it can also be a mediating factor, subjective repositioning and facing the difficulties regarding access and treatment in public health services. However, few studies have been dedicated to the theme of populations in rural contexts.

In Brazil, the study by Costa and Ludermir (2005) is one of the few that invest in the relationship between social support, mental health and the rural context. It's an investigation on the prevalence of mental disorders and their association with social support in a community on the rural area of the Zona da Mata in Pernambuco. 
As for research on alcohol consumption and social support in rural areas, there are still few studies on it in the country. However, some researches point to factors such as the presence of social support, leisure access and public policy are inversely related to the abusive use of alcohol in rural areas (Ronzani, 2008). Thus, considering the social, economic and family impact from mental health issues, beyond the scarcity of studies that deal with the theme in rural contexts, we developed this research with the purpose of investigating the life conditions and forms of social support in agrarian reform settlements in Piauí facing common mental disorders and abusive use of alcohol.

\section{Method}

It's a cross-cutting study, of a descriptiveexploratory character, made in two agrarian reform settlements in the state of Piauí: Santo Antônio do Campo Verde, placed in the town of Sigefredo Pacheco and the Marine Extrativist Reservation of the Parnaíba Delta, located in the north of the state. All residents over 18 in the two of the settlements participated in the study, characterizing as exclusion criteria refusal in participating the research and the existence of medical or psychological conditions that made participation impossible. The participants were interviewed in their homes. Among the tools for data collection the following were used: (a) A Socio-Demographic Questionnaire, a modified version of the material elaborated by the Geology Department in Federal University of Rio Grande do Norte (UFRN), organized via the following aspects: income, occupation, education, number of residents in-house, age, sex, religion, settlement infrastructure, health conditions, public health service access as well as access to income transference, credit and rural assistance. The original questionnaire approached matters related to land reality, details in infrastructure in residences, agricultural production, equipments, input, among others that were not approached by this investigation, which also updated informations on social policy. (b) Self-Reporting Questionnaire (SRQ-20) for detecting cases of common mental disorders. It's a validated questionnaire in Brazil (Mari \& Williams, 1986) and recommended by the World Health Organization for community studies and primary attention to care. It is composed by 20 items, with a yes or no type of answer. The obtained scores signal a possible presence of mental disorders or emotional discomfort (evaluated constructed), varying from 0 (no possibility) to 20 (very likely). We adopted the cross-cut of 7 or more positive answers as an indication of common mental disorders, based on studies that deal with primary care services users in Brazil (Gonçalves, Stein, \& Kapczinski, 2008). (c) Alcohol Use Disorders Identification Test (AUDIT) to detect cases of alcohol use. It's a validated questionnaire in Brazil (Babor, Higgins-Biddle, Saunders, \& Monteiro, 2001) and recommended by World Health Organization (WHO) in detecting excessive alcohol consumption and support to brief intervention by the professionals at AP. It contains ten questions about consumption and symptoms of problematic use of alcohol in the last 12 months. A quantitative cut off point was adopted where a score of 08 or more items are classified as dangerous, harmful or addictive consumption, as established by the mark. (d) Medical Outcomes Study (MOS-SSS) for cases where the person interviewed has a SRQ-20 and/or AUDIT score. It is the Social Support Scale developed by Sherbourne and Stewart (1991) and validated in Brazil by Griep, Chor, Faerstein, Werneck, and Lopes (2005). As a construct it is elaborated and subdivided in five known dimensions: Tangible support (available resources and material help); Informational support (the existence of people with the ability to find information and advice); Affective Support (people who demonstrate love and affection); Emotional Support (External demonstration of trust, listening and interest); and the Positive Social Interaction Support (how one relates and has available company for fun and relaxation; Griep et al., 2005). The MOS-SSS is composed by 19 questions. For each answer there is an attributed score varying from 1 (never) to 5 (always). Two groups were established for each type of support, divided as low and high social 
support, with an average statistical base from the data in each dimension.

About the use of the aforementioned tools, despite the effort of a few efforts that tried to validate it in rural populations (Costa \& Ludermir, 2005; Moretti-Pires \& Corradi-Webster, 2011), we understand that the same were elaborated thinking of urban populations, and that its application in rural means needs to consider the context and the singularities that mark the life stories of these people.

The analysis of the data, based on Software Statistical Package for the Social Sciences (SPSS) for Windows, 20 version, utilized absolute, relative and average frequency (maximum and minimum value) and the comparison between groups was done through Person's qui-square test, considering the level of significance the value of 0.05 . Finally, the ethical procedures of the $\mathrm{n}^{\circ} 466 / 12$ Resolution on the National Health Council, with CAAE No 54297716.6.0000.5214 of the Federal University of Piaui (UFPI) Ethic Research Committee were done, having all the participants signing the Term of Consent.

\section{Results and Discussions}

\section{Socio Demographic Characterization of Researched Settlements and Families}

Piauí counts with a population of $3,118,360$ inhabitants, distributed in 224 municipalities $\left(12,4 \mathrm{hab} / \mathrm{km}^{2}\right)$, with $34.2 \%$ of the population living in rural areas. The national average is $15.6 \%$ (Instituto Brasileiro de Geografia Estatística [IBGE], 2010). It has the second worst household in the country ( $\mathrm{R} \$ 1,354)$. In the last ten years, half of the population in extreme poverty (total of 800 thousand) have experienced improvement in their life conditions. Among the main elements that helped the increase and redistribution of income is the adoption of income transference policies, minimum wage and credit raise. Furthermore, Piauí has one of the highest $(21.10 \%)$ rates of illiteracy in Brazil, where these rates are higher in rural areas due to difficulties in access to schools and the use of child labour (Programa das Nações Unidas para o Desenvolvimento [PNUD], 2010). According to Instituto Nacional de Colonização e Reforma Agrária (INCRA), in Piauí there are a total of 1,193 that live in 497 rural settlements.

We limited the study, as mentioned previously, to two agrarian reform settlements: one located in the territory of "Coastal plains" known as Marine Extrativist Reservation of the Parnaíba Delta (RESEX), more specifically in the Canárias Community; and another one situated in the territory of "Carnaubais", known as Santo Antonio do Campo Verde, located in the township of Sigefredo Pacheco.

RESEX is located in the Delta of the Americas. Although it is administratively linked to the township of Araioses, in Maranhão, INCRA considers it a settlement area belonging to the Piaui state. The settlement is composed by an agglomeration of communities spread through islands in the Parnaíba river delta: the Ilhas Canarias, Passarinho, Caiçara, Torto and Morro do Meio, all of which have their extension bathed by the river. The access is done by small and large vessels. The Parnaíba Delta is an environmental protection area, created in 2005, managed by the INCRA and the Instituto Chico Mendes de Conservação da Biodiversidade (ICMBio), although it was long occupied by its dwellers.

The data collection in the RESEX was largely focused in the communities in the Ilhas das Canarias, in function of the following criteria: a greater size of population (largest island in the Delta), large socioeconomic area of vulnerability and easy access when compared to the other communitie in the region. Two hundred and sixty-nine families participated in the study, in a total of 1,060 individuals. It's a population made of single young adults $(53.16 \%)$, with a male prevalence $(51,51 \%)$, incompletecomplete elementary school education $(57.79 \%)$ and family monthly income of half a minimum wage (54.25\%). Their main forms of sustenance are fishing, income transference policies and retirement.

As for the settlement in Santo Antonio do Campo Verde, it is located in the midwest of the Piauí state, in the township of Sigefredo Pacheco, $8 \mathrm{~km}$ from the township's center. It was created through the struggles of the Movimento 
dos Sem Terra (MST), alongside with the Sindicato dos Trabalhadores Rurais, in a period of large mobilization of rural social movements and syndicates, as it is a large extension of unproductive land, of about ten thousand hectares. In the year of 1996 it was decreed that it would be expropriated, and in 1997 INCRA started the first registration process which would lead to forming the settlement; it was only in 1998 that houses were built.

One hundred and forty three families in Santo Antonio do Campo Verde participated in the study, totaling 432 individuals. The population was primarily young men $(51.62 \%)$, and married (52.2\%), which differs from the Canarias community, whose inhabitants are in their majority, single. As for education levels, 56.23\% have some degree of basic education. Families are sustained by family agriculture, income transference policies and retirement. Most of the settlement's population has a half a minimum wage income.

In what refers to living conditions in the settlement, most houses were masonry, with ceramic tiles and floor tiles. Access to water is brought by the public network in most houses in Santo Antonio, and a well in the Canarias. The water treatment is done by filtering or chlorination. As for human waste, it is dealt with by a septic tank and garbage is public trash disposal or burning. On the access to health services, $81.82 \%$ of families in the Santo Antonio settlement and $89.14 \%$ in the Canárias report that they are assisted by Agente Comunitário de Saúde (ACS) - community health agents. However, what is seen through reports by the interviewed is that ACS is not regular. Months can go by without home visits, showing a fragility of the care and attention network. In what regards health units services, both settlements have said that they do get care; the first settlement has a health unity in the center of town, and the second one in the community area. The most common illnesses in both settlements are: flu, pneumonia and other respiratory diseases, smallpox, chickenpox, worms, diarrhea and hypertension and diabetes. Despite the Canarias counting with a Family Health Strategy unity, the levels of access to health programs are lower than the ones in Santo Antonio.

On social programmes, $75.52 \%$ of families are benefit claimants for the Bolsa Familia programme in Santo Antonio and $70.63 \%$ in the Canarias. About development credit, $62.24 \%$ of families in Santo Antonio get it, but only $2.97 \%$ of the Canarias do. The same situation is found in the National Programme of Family Agriculture (PRONAF), with $44.06 \%$ of families in Santo Antonio receiving it, while $2.60 \%$ of Canarias families do. These aspects directly repercute in the housing and work and income situations of the settlements.

The data found in both settlements show a similar reality to the one found in rural areas of the country, marked by vulnerable conditions of poverty and misery. Even though social indexes have improved, as well as to housing, education, health and leisure conditions in rural areas in Brazil, a result of implementation and expansion of social and agrarian projects, it's still possible to witness a considerable level of illiteracy, difficulty accessing public services and technical assistance, precarious work conditions and dependence on income transference programmes, lack of proper highways, transportation, means of communication, few hydrics resources, proper waste disposal, and maintenance of rural-urban migration seeking health, education, work and income services. That reality was found in Santo Antonio and in the Canarias.

\section{Ordinary Mental Health Disorders and Social Support}

Of a total of 1492 individuals living in both settlements, the SRQ-20 was applied to 767 individuals, with 255 being in Santo Antonio and 507 in the Canarias. Five questionnaires were discarded due to filling problems. Of all valid questionnaires, $21 \%$ were above the cut off point, marking then, a possible indication of common mental disorder.

In both of the settlements, a majority of women $(32.46 \%)$ were above the cut off grade, while men had a smaller percentage $(26.17 \%)$. The results by settlement are surprising, considering that the level of women with a 
Table 1

SRQ-20 Men and Women

\begin{tabular}{|c|c|c|c|c|c|c|}
\hline \multirow[b]{2}{*}{ Santo Antônio } & \multicolumn{2}{|c|}{ Below cut-off point } & \multicolumn{2}{|c|}{ Above cut-off point } & \multicolumn{2}{|c|}{ Total (PI) } \\
\hline & $N^{o}$ & $\%$ & $N^{\mathrm{o}}$ & $\%$ & $N^{\mathrm{o}}$ & $\%$ \\
\hline Male & 99 & 50.25 & 26 & 44.83 & 125 & 49.02 \\
\hline Female & 98 & 49.75 & 32 & 55.17 & 130 & 50.98 \\
\hline Total & 197 & 100 & 58 & 100 & 255 & 100 \\
\hline \multicolumn{7}{|l|}{ Canárias } \\
\hline Male & 189 & 46.67 & 28 & 27.45 & 217 & 42.80 \\
\hline Female & 216 & 53.33 & 74 & 72.55 & 290 & 57.20 \\
\hline Total & 405 & 100 & 102 & 100 & 507 & 100 \\
\hline
\end{tabular}

higher score is more expressive in the Canarias $(72.55 \%)$, if compared with Santo Antonio $(55.17 \%)$, as shown in the following table.

When the data of those who scored above the cut-off point were cross referenced with the socio-demographic data, from a perspective of trying to consider the life context of these people, it's possible to observe that not only are the majority of them women, but also between 30 to 49 years old, with varying levels of basic education, married and with a family income of one minimum wage.

In the few works that deal specifically with rural populations, authors such as Dimenstein et al. (2016), signal a possible association between income, education level, gender and larger incidence of common mental disorders, although they do not indicate a deterministic and causal relationship. Authors such as Costa and Ludermir (2005), Pinho and Araújo (2012) understand that the larger prevalence of these disorders in women in rural areas is due to many factors such as an high domestic workload taking care of children, low gratification, submission to a partner in matters of the household, and the lack of visibility in their accomplishments in domestic labour.

On the other hand, the gender relations between men and women involving ordinary disorders have particular properties (Dimenstein et al., 2016). For these authors, while male illness in rural areas is more associated to the agricultural workload, precarious work conditions, loss physical strength and the appearance of chronic illness, in women it is related to domestic work, characterized by the double workload, the number of children, gendered violence by significant others, stressful life events such as loss of near relatives, divorce, all of which contribute to triggering or making mental illness worse.

Loureiro et al. (2015) draws the eye to the social determinants in the process of mental illness, ranking the life conditions and social inequalities as predisposed elements for psychic suffering. In this way, the socio economic reality in the investigated settlements, previously presented, indicates difficulty in accessing goods and services such as health, education, work, transportation, public policies, sanitation, all of which can make the settlement's populations even more vulnerable to psychic illnesses-suffering situations.

In detailing the results related to the dimensions of the SRQ-20, in Santo Antonio, the women have shown higher scores in all of the instrument's dimensions if compared to men, specially in regards to depressive thoughts (63.08\%), followed by decrease of vital energy $(58.29 \%)$, somatic symptoms $(57.14 \%)$ and anxious-depressive humor. In the Canarias, the dominance of women in the SRQ dimensions involves somatic symptoms (63.21\%), decreased energy (62.9\%), anxious-depressive humor (62.47\%), depressive thoughts $(56.25 \%)$.

In general, the data with SRQ dimension, 
especially in Santo Antonio, draw attention to the large percentage of people who scored in the depressive thoughts category, since that out of 255 interviewees, $51 \%$ have scored on that category. Most of it, once again, falls onto women which is a concerning data once we have in mind the gender dimension in the ways to express sickness, so that matters of depression, anxiety, and suicidal ideation affect women more than men (Rabasquinho \& Pereira, 2007). When asked about thoughts of ending their own lives, out of the total of the research sample in both settlements, 102 people have said "yes", which means $13.4 \%$ of cases, suggesting an expressive data that is concerning and demands challenges to mental health policies. Out of these, $28.4 \%$ live in Santo Antonio and $74.6 \%$ in the Canarias, with a female prevalence.

Those who were above the cut-off point at SRQ-20 $(n=160)$, the MOS-SSS was applied. The treatment of the results in Social Support Scale (MOS-SSS) excluded five questionnaires, with only 155 remaining ( $\mathrm{AS}=55$ and $\mathrm{CN}=100$ ), as shown in the following table.

Table 2

Social Support (MOS-SSS) of SRQ-20 Respondents

\begin{tabular}{|c|c|c|c|c|c|c|c|}
\hline & \multirow{3}{*}{ Dimension } & \multicolumn{6}{|c|}{ Settlements } \\
\hline & & \multicolumn{2}{|c|}{ Santo Antônio } & \multicolumn{2}{|c|}{ Canárias } & \multicolumn{2}{|c|}{ Total (PI) } \\
\hline & & $N^{\mathrm{o}}$ & $\%$ & $N^{\mathrm{o}}$ & $\%$ & $N^{\mathrm{o}}$ & $\%$ \\
\hline \multirow{3}{*}{ Tangible support } & Below average (zero to 95) & 31 & 56.36 & 59 & 59 & 90 & 58.06 \\
\hline & Above average (above 95) & 24 & 43.64 & 41 & 41 & 65 & 41.94 \\
\hline & Total & 55 & 100 & 100 & 100 & 155 & 100 \\
\hline \multirow{3}{*}{ Affective Support } & Below average (zero to 95) & 33 & 60 & 51 & 51 & 84 & 54.19 \\
\hline & Above average (above 95) & 22 & 40 & 49 & 49 & 71 & 45.81 \\
\hline & Total & 55 & 100 & 100 & 100 & 155 & 100 \\
\hline \multirow{3}{*}{ Emocional Support } & Below average (zero to 90) & 31 & 56.36 & 56 & 56 & 87 & 56.13 \\
\hline & Above average (above 90) & 24 & 43.64 & 44 & 44 & 68 & 43.87 \\
\hline & Total & 55 & 100 & 100 & 100 & 155 & 100 \\
\hline \multirow{3}{*}{$\begin{array}{l}\text { Informational } \\
\text { support }\end{array}$} & Below average (zero to 90) & 31 & 56.36 & 53 & 53 & 84 & 54.19 \\
\hline & Above average (above 90) & 24 & 43.64 & 47 & 47 & 71 & 45.81 \\
\hline & Total & 55 & 100 & 100 & 100 & 155 & 100 \\
\hline \multirow{3}{*}{$\begin{array}{c}\text { Positive Social } \\
\text { Interaction Support }\end{array}$} & Below average (zero to 100 ) & 55 & 100 & 100 & 100 & 155 & 100 \\
\hline & Above average (above 100) & 0 & 0 & 0 & 0 & 0 & 0 \\
\hline & Total & 55 & 100 & 100 & 100 & 155 & 100 \\
\hline
\end{tabular}

As for the dimensions around the social support perceived by the individuals with common mental disorders, Table 2 shows that there are those who are below average, meaning they report they don't count with enough social support; those who are above average, that say they count with some form of social support. And among the dimensions investigated in the settlements, generally speaking, the majority of the percentage interviewed is below average, whether in the dimension of Tangible support (58.06\%), Emotional Support (56.13\%), Affective Support (54.19\%) and informational support $(54.19 \%)$. In regards to the specific dimension of Positive Social Interaction Support, all the results were below average, which can 
signal lack of spaces and moments of convivence, especially in regards to community living, with few leisure activities as well as culture and social interaction in the settlements. In this way, it's understood that based in the fragile infrastructure and material life conditions, as well as the lack of available resources in the settlements, that such factors can contribute, in some ways, with the reason why people with psychic suffering see their received social support as insufficient in the investigated dimensions. Such aspects can be looked into in depth by future studies with more specific statistical analysis, that can go beyond the exploratory character of this study.

Considering the pattern of answers between men and women on social support, we saw that the gender factor can impact in distinct ways those with strong indications of common mental disorders. Out 155 interviewees in the MOSSSS, $68,38 \%$ were women who signalled they count with low support in all dimensions. This is a worrying data once we keep in mind women suffer more strongly with this lack of protection.

Crossing every dimension of social support with the profile of people who scored below the cut-off point in SRQ-20, some specific points were noted. In all of the dimensions, it's married people who seem to count with the lowest support. In the case of women, the percentage that indicates low's support seems to be much more significative $(74.1 \%$ in material, $81 \%$ in emotional, $77.4 \%$ in affective, $78 \%$ of information and $79.6 \%$ in positive interaction) than in the case of married men $(53.1 \%$ in material, $51.6 \%$ in emotional, affective and information; and $63.5 \%$ in positive interaction). However we can notice a reasonable number of single men in this condition $(28.1 \%$ in tangible support, $25.8 \%$ in emotional, affective and informational support and $19.2 \%$ in positive interaction). However, there is highlight of low support among women that have children $(70.7 \%$ in material, $70.7 \%$ emotional, $75.5 \%$ in affective, $64.4 \%$ information; and $70.9 \%$ in positive interaction), among the men the highlight is for those without children (50\% in material, $58.1 \%$ in the emotional, affective and information and $53.8 \%$ positive interaction), indicating a possible overload of women with children and the absence of family life as elements associated to suffering in men and women.

As for occupation, the women that get low support are housewives that also work in agrarian work and fishing $(67.2 \%$ in material, $72.4 \%$ in emocional, $73.6 \%$ in affective, $64.4 \%$ of information and $70.9 \%$ in positive interaction). The men are farmers and fishers (65.6\% in material, $58.1 \%$ in emotional, $58 \%$ in affective, $58.1 \%$ of information e $63.5 \%$ in positive interaction). As for education, women with less support are more educated than men. The women in this condition have elementary school education $(48.3 \%$ in material, $58.6 \%$ in emotional, $56.6 \%$ in affective, $57.6 \%$ of information and $56.3 \%$ in social interaction), while the men are in large numbers illiterate $53.1 \%$ in material, $64.5 \%$ in emotional, $63.5 \%$ in affective, $64.5 \%$ in information and $53.8 \%$ in social interaction). As for income, both men and women with lower support are in the group of half a minimum wage, although the percentage of women $(55.10 \%$ in material, $63.80 \%$ in emotional, $60.40 \%$ in affective and information; and $59.20 \%$ positive interaction) overperforms in relation to men in all dimensions (46.90\% in material, $51.60 \%$ in emocional, in affective and in informação; and $48.10 \%$ positive interaction).

To summarize, we consider that these women seem to experience more worrying levels of vulnerability in these settlements. The fact they deal with a high workload, having to do both the housework and take care of children, husband, farm or fishing activity, and take on the role of carers, which is historically and socially attributed to them, all seems to result in intense physical and emotional overload, which is shown, possibly, by the symptoms and signs of common mental disorders. All the effort and suffering generated are not recognized by their partners and children, which can certainly cause a severe impact in the perception of social support, especially in what concerns the material, emotional and affective dimensions.

If we take tangible support as an analyzer of the impact of gender relations on the perceived 
support, we notice that in the case of women, should they get ill and need to go to the doctor, or need help in their daily chores and care of their children, they have said to count with very little help since these functions are seen as their responsibility, differently from men, who usually, count with support and help from their wives and children when they need it, and that feel recognized for it. Furthermore it is evident that for men, marriage and children is a protective factor of the offer of social support. Single men or childless men have a higher rate of insatisfaction in regard to the received support. Such aspects demand new research to evaluate the possible relations between these factors.

In the same way, the lack of support from people that are close (partners, children, family members and neighbours) in the sense of showing love and affection (Affective Support), as well as those who can count with trust, listening and caring relationships (emotional support) can be the reflex of the wide load of domestic work, which at times invisible and lonely, pushes women away from the settlements social life. Besides that, there is still the sexist view of women's place being at home. Women identify few people to trust and share their worries and fears or even people to have fun with. When they do find these people, they usually go to their children, their own mothers or close relatives (Positive Social Interaction support). Few count with their partner's support. As for the Informational Support, it it is suggested that because of the lack of the backing of health professionals and the existence of strong social and communitary bonds, there is fragility and lack of the support received, mostly in regards to formal networks from health policies and other social protection equipments.

Back to Table 2, we can see that the Canarias settlement, which counts with more precarious infrastructure and conditions of life, tangible support is said to be below average for $59 \%$ of the respondents, followed by Emotional Support (56\%), informational support (53\%), Affective Support $(51 \%)$, indicating unsatisfactory indexes in all dimensions. In Santo Antonio there is a highlight for the Affective Support (60\%), considering the low perception of trust, listening and caring in the face of suffering relationships. In the other dimensions that involve material, emotional and informational support, the score was also below average, as low support (56.6\%). As for positive social interaction, we can see that in both settlements all respondents felt like they had insufficient support, being a dimension to consider in preventive and health promotion strategies. Next, we will talk about the cases of alcohol and social support in the investigated settlements.

\section{Cases of Abusive Use of Alcohol and Social Support}

As for AUDIT, from a total in 1,492 individuals living in the settlements, a tracking tool was applied regarding the use of alcohol on 767, with 257 in Santo Antonio and $(49.03 \%$ men and $50.97 \%$ women) and 510 in the Canarias (42.75\% and $57.25 \%$ women).

In general, the results indicated 89 cases with possible risk consumption, harmful use and addiction in both settlement, which corresponds to $11.67 \%$. The majority of them are located in the Canarias, being 55 men and 16 women, while in Santo Antonio there are 16 men and 02 women. The men are in larger number in terms of alcohol use. This result was expected and indicated in latest researches done by Instituto $\mathrm{Na}$ cional de Ciência e Tecnologia para Políticas Públicas do Álcool e outras Drogas (INPAD, 2012) and Organização Pan Americana de Saúde (OPAS, 2015), although there's been an increase of women using alcohol.

Considering the particular features of every settlement, the Canarias present a larger use of alcohol if compared to Santo Antonio. The Canarias are a fishing community, where a previous study evidenced a narrow relationship between alcohol use and work routine, especially in coastal communities, where a majority of fishermen ingests alcohol to withstand the working conditions such as sunlight exposure for prolonged periods of sea fishing, the lonely work at night of picking crabs, as well as enduring the mosquito spread on swamps and other issues also justify the use of alcohol (Dimenstein et al., 2016). 
Table 3

Distribution from Alcohol Use Pattern

\begin{tabular}{ccccccc}
\hline & \multicolumn{2}{c}{ Santo Antônio } & \multicolumn{2}{c}{ Canárias } & \multicolumn{2}{c}{ Total } \\
\cline { 2 - 7 } & $N^{\mathrm{o}}$ & $\%$ & $N^{\mathrm{o}}$ & $\%$ & $N^{\mathrm{o}}$ & $\%$ \\
\hline Low Risk & 239 & 93 & 439 & 86.08 & 678 & 88.40 \\
Risk & 12 & 4.67 & 57 & 11.18 & 69 & 9 \\
Harmful & 1 & 0.39 & 9 & 1.76 & 10 & 1.30 \\
Addiction & 5 & 1.95 & 5 & 0.98 & 10 & 1.30 \\
Total & 257 & 100 & 510 & 100 & 767 & 100 \\
\hline
\end{tabular}

In what concerns the distribution by use pattern, illustrated on Table 3, in Santo Antonio $4.67 \%$ of the population practices a risk use, followed by harmful use $(0.39 \%)$ and addictive $(1.95 \%)$. In the Canarias there's also a predominance of risk use $(11.18 \%)$, followed by harmful use $(1.76 \%)$ and addictive $(0.98 \%)$. Cross referencing the data of those who have shown a pattern of problematic use of alcohol with their socio-demographic profile, we observe that they individuals with a family income of half to a 1 minimum wage, have different levels of basic education, married, with children, young adults, being either farmers or fishermen. Their housing, income, waste disposal, access to clean water, education and healthcare is precarious, with negative impact to their welfare and life habits of individuals and the community.

In relation to social support, those who have scored in AUDIT above cut-off point $(n=89)$, and responded to MOS-SSS, $82.1 \%$ are men and $17.9 \%$ are women. Most of the respondent with low affective support are single $(41.7 \%)$ while those who count with high levels are married $(62.5 \%)$. The majority with low tangible support does not have children (55\%), while those with high support do have children $(56.80 \%)$. In Table 4 we can see the results of social support and the standard use of alcohol.

Results suggest differences between the sexes, because while men count with high material, affective and emotional support, women perceive low support in all dimensions. This data can indicate that despite there being less women that use alcohol in a problematic way in comparison to men, the gender issue is a defining element of vulnerability for women, since they count with less support, associated with stigma and a higher degree of social reproach for women in the community, since once they drink they deviate from the role of a good mother, carer for their children, husband and house (Alves, 2015). For Zanello (2016), the gender roles attributed, above all, in marriage, constitute a protection factor to the mental health of men over women. The care for children, husband, family, as well as the invisibility of the domestic work leads many women to being worn down physically and suffer psychologically. That means that the crossing of gender impacts of the perception of the received social support.

The data suggest, still, that in the cases where the consumption patterns are problematic, there is a lower perception of social support in all its dimensions. In risk use, for example, it was observed sufficient support in the material, affective and emotional dimensions, whereas the informational supportwas insufficient. This can show some difficulties in accessing the region's professional help. In harmful use, low support was found in two dimensions: Affective and Emotional. Among those with addictive use, we found low support in three dimensions: Material, Emotional, and Informational. Regarding positive interaction all respondents are below average on support offers, the same as with common mental disorders. These aspects can reveal a worrying data, because they might 
Table 4

Social Support (MOS-SSS) of the AUDIT Respondents - by Use Pattern

\begin{tabular}{|c|c|c|c|c|c|c|c|c|c|}
\hline & & \multicolumn{8}{|c|}{ AUDIT_category } \\
\hline \multirow{2}{*}{\multicolumn{2}{|c|}{ Dimension }} & \multicolumn{2}{|c|}{$\begin{array}{c}\text { Risk } \\
(8 \text { até } 15)\end{array}$} & \multicolumn{2}{|c|}{$\begin{array}{l}\text { Harmful } \\
\text { (16 até 19) }\end{array}$} & \multicolumn{2}{|c|}{$\begin{array}{l}\text { Addiction } \\
\text { (20 ou mais) }\end{array}$} & \multicolumn{2}{|c|}{ Total } \\
\hline & & $N$ & $\%$ & $N$ & $\%$ & $N$ & $\%$ & $N$ & $\%$ \\
\hline \multirow{3}{*}{ Support Material } & $\begin{array}{c}\text { Below average } \\
\text { (zero to 95) }\end{array}$ & 28 & 43.08 & 5 & 50 & 7 & 77.78 & 40 & 47.62 \\
\hline & $\begin{array}{c}\text { Above average } \\
\text { (above 95) }\end{array}$ & 37 & 56.92 & 5 & 50 & 2 & 22.22 & 44 & 52.38 \\
\hline & Total & 65 & 100 & 10 & 100 & 9 & 100 & 84 & 100 \\
\hline \multirow{3}{*}{ Affective Support } & $\begin{array}{l}\text { Below average } \\
\text { (zero to 95) }\end{array}$ & 26 & 40 & 7 & 70 & 3 & 33.33 & 36 & 42.86 \\
\hline & $\begin{array}{c}\text { Above average } \\
\text { (above } 95)\end{array}$ & 39 & 60 & 3 & 30 & 6 & 66.67 & 48 & 57.14 \\
\hline & Total & 65 & 100 & 10 & 100 & 9 & 100 & 84 & 100 \\
\hline \multirow{3}{*}{ Support Emocional } & $\begin{array}{c}\text { Below average } \\
\text { (zero to 90) }\end{array}$ & 31 & 47.69 & 6 & 60 & 6 & 66.67 & 43 & 51.19 \\
\hline & $\begin{array}{c}\text { Above average } \\
\text { (above } 90 \text { ) }\end{array}$ & 34 & 52.31 & 4 & 40 & 3 & 33.33 & 41 & 48.81 \\
\hline & Total & 65 & 100 & 10 & 100 & 9 & 100 & 84 & 100 \\
\hline \multirow{3}{*}{$\begin{array}{l}\text { Informational } \\
\text { support }\end{array}$} & $\begin{array}{c}\text { Below average } \\
\text { (zero to } 90)\end{array}$ & 34 & 52.31 & 5 & 50 & 5 & 55.56 & 44 & 52.38 \\
\hline & $\begin{array}{c}\text { Above average } \\
\text { (above } 90)\end{array}$ & 31 & 47.69 & 5 & 50 & 4 & 44.44 & 40 & 47.62 \\
\hline & Total & 65 & 100 & 10 & 100 & 9 & 100 & 84 & 100 \\
\hline \multirow{3}{*}{$\begin{array}{l}\text { Positive interaction } \\
\text { Support }\end{array}$} & $\begin{array}{c}\text { Below average } \\
\text { (zero to 90) }\end{array}$ & 65 & 100 & 10 & 100 & 9 & 100 & 84 & 100 \\
\hline & $\begin{array}{c}\text { Above average } \\
\text { (above } 90)\end{array}$ & 0 & 0 & 0 & 0 & 0 & 0 & 0 & 0 \\
\hline & Total & 65 & 100 & 10 & 100 & 9 & 100 & 84 & 100 \\
\hline
\end{tabular}

indicate the need for actions and health strategies that focus on strengthening the bond and the social support in both the socio-familiar network and the communitary one of these individuals, as well as broadening actions to divulge knowledge and informations about the problems associated with the use of alcohol and the possibility of care. Miranda, Simpson, Azevedo, and Costa (2006) highlight the importance of more investment in the relationship between health teams with family members to strengthen care actions, keeping in mind that family is often is a protective factor for mental health cases. However, there are situations where it's frequent to find fragile family relations, like loss of friendship and professional relations.

The people that have addictive use show a lower age average (36.6 years, $S D=16)$, if compared to the ones with risky and harmful use (38.7 years, $S D=13.6 ; 44.1$ years, $S D=16.3$, respectively). Which means it is a group of young people in very vulnerable situations, which 
suggests they count with low social support. Worryingly, the epidemiologist researches have registered that people resort to abusive use of alcohol, as well as that the consumption of it starts earlier both for men and women (OPAS, 2015).

\section{Final Considerations}

This study has shown that the different forms of mental illness-suffering might have a strong relationship with the conditions of life, work, health and education of a population, strengthening the discussion on Social Determination of Mental Health, a still limited debate within the health teams and the makers of health policies and programmes. The cases identified in research that involve common mental disorders and problematic patterns of alcohol consumption illustrate this possible relationship, as well as the fact that social support can be conditioned by a complex network of factors. These are aspects that corroborate the study by Rodrigues and Madeira (2009) when they said that social support doesn't only play an important role in determining levels of health and welfare of individuals, in seeking helping and maintaining their treatment, but it's also determined by the contexts and conditions of life of a population.

Thus we highlight promoting preventive health actions Estratégia Saúde da Família/ESF e Núcleo de Apoio à Saúde da Família (Family Health Strategy - ESF and Support to Family Health Core - NASF), and the strengthening of socio familiar services like Centros de Referência da Assistência Social (Reference Centers of Social Work [CRAS]) in the Sistema Único de Assistência Social (SUAS). These teams must strengthen their networks of information, interaction and community life, supported by their own territory.

On the other hand, orientation of professional actions and services offered by health and social work, based in the dimensions of social support, can decrease the levels of vulnerability and the impact of gender issues and life conditions on the mental health of settlement's popu- lations, because while in women, illness indicates a relationship to double shift with domestic work and children, gender violence, with men it's evident the overload of rural work, the loss of physical vitality and stressful situations such as divorce, among others.

\section{Authors' Contributions}

Substantial contribution in the concept and design of the study: (João Paulo Macedo, Magda Dimenstein)

Contribution to data collection: (Brisana Índio do Brasil de Macêdo Silva, Hédina Rodrigues de Sousa, Ana Paula Almeida da Costa)

Contribution to data analysis and interpretation: (João Paulo Macedo, Brisana Índio do Brasil de Macêdo Silva, Hédina Rodrigues de Sousa, Ana Paula Almeida da Costa )

Contribution to manuscript preparation: (João Paulo Macedo, Brisana Índio do Brasil de Macêdo Silva, Hédina Rodrigues de Sousa, Ana Paula Almeida da Costa )

Contribution to critical revision, adding intelectual content: (João Paulo Macedo, Magda Dimenstein).

\section{Conflicts of interest}

The authors declare that they have no conflict of interest related to the publication of this manuscript.

\section{References}

Abreu-Rodrigues, M. A., \& Seidl, E. M. F. (2013). Apoio social a pacientes coronarianos: Efeitos de intervenção comportamental com um familiar. Estudos de Psicologia (Campinas), 30(4), 619628. doi: 10.1590/S0103-166X2013000400015

Alves, T. M. (2015). A diversidade dos usos de substâncias psicoativas por mulheres em ParnaibaPI a partir de suas histórias de vida: Uma perspectiva de gênero (Master thesis, Universidade Federal do Piauí, Teresina, PI, Brazil).

Babor, T. F., Biddle-Higgins, J. C., Saunders, J. B., \& Monteiro, M. G. (2001). AUDIT: The Alcohol Use Disorders Identification Test: Guidelines for use in primary health care. Geneva: World Health Organization. Retrieved from http://apps. 
who.int/iris/bitstream/10665/67205/1/WHO MSD_MSB_01.6a.pdf

Costa, A. G., \& Ludermir, A. B. (2005). Transtornos mentais comuns e Apoio social: Estudo em comunidade rural da Zona da Mata de Pernambuco, Brasil. Cadernos de Saúde Pública, 21(1), 7379. doi: 10.1590/ S0102-311X2005000100009

Dimenstein, M. D. B., Leite, J. F., Macedo, J. P. S., \& Dantas, C. M. B. (Eds.). (2016). Condições de vida e saúde mental em contextos rurais. São Paulo, SP: Intermeios.

Gonçalves, D. M., Stein, A. T., \& Kapczinski, F. (2008). Avaliação de desempenho do SelfReporting Questionnaire como instrumento de rastreamento psiquiátrico: Um estudo comparativo com o Structured Clinical Interview for DSM-IV-TR. Cadernos de Saúde Pública, 24(2), 380-390. doi: 10.1590/S0102311X2008000200017

Griep, R. H., Chor, D., Faerstein, E., Werneck, G. L., \& Lopes, C. S. (2005). Validade de constructo de escala de apoio social do Medical Outcomes Study adaptada para o português no Estudo PróSaúde. Caderno de Saúde Pública, 21(3), $703-$ 714. doi: 10.1590/S0102-311X2005000300004

Instituto Brasileiro de Geografia e Estatística. (2010). Cidades. Retrieved from http://www.cidades. ibge.gov.br/xtras/home.php

Instituto Nacional de Ciência e Tecnologia para Políticas Públicas do Álcool e outras Drogas. (2012). II Levantamento Nacional de Álcool e Outras Drogas - LENAD. São Paulo, SP: Author.

Jussani, N. C., Serafim, D., \& Marcon, S. S. (2007). Rede social durante a expansão da família. Revista Brasileira de Enfermagem, 60(2), 184-189. doi: 10.1590/S0034-71672007000200011

Loureiro, A., Lima, J., Partidário, M. R., \& Santana, P. (2015). Condicionantes de saúde mental e os instrumentos de avaliação de impactos. In P. Santana (Ed.), Territórios e saúde mental em tempos de crises (pp. 11-27). Portugal: Universidade de Coimbra. doi: 10.14195/978-989-261105-1

Mari, J. J., \& Williams, P. A. (1986). Validity study of a psychiatric screening questionnaire (SRQ$20)$ in primarycare in the city of São Paulo. British Journal of Psychiatry, 148, 23-26.

Miranda, N., Simpson, A., Azevedo, M., \& Costa, S. (2006). O impacto negativo dos transtornos do uso e abuso do álcool na convivência familiar. Revista Eletrônica de Enfermagem, 8(2), 222232.

Moretti-Pires, R. O., \& Corradi-Webster, C. M. (2011). Adaptação e validação do Alcohol Use Disorder Identification Test (AUDIT) para população ribeirinha do interior da Amazônia, Brasil. Cadernos de Saúde Pública, 27(3), 497509. doi: 10.1590/S0102-311X2011000300010

Organização Pan Americana de Saúde. (2015). Informe sobre la situación regional sobre el alcohol y la salud en las Américas. Washington, DC: Author.

Peña, R. F. (2005). Redes Sociales, apoyo social y salude. Periferia, 3, 1-16. Retrieved from http://revista-redes.rediris.es/Periferia/english/ number3/periferia_3_3.pdf

Pinho, P. S., \& Araújo, T. M. (2012). Associação entre sobrecarga doméstica e transtornos mentais comuns em mulheres. Revista Brasileira de Epidemiologia, 15(3), 560-572. doi: 10.1590/ S1415-790X2012000300010

Programa das Nações Unidas para o Desenvolvimento. (2010). Relatório de Desenvolvimento Humano 2010- A verdadeira riqueza das nações: Vias para o desenvolvimento humano. New York: Author.

Rabasquinho, C., \& Pereira, H. (2007). Gênero e Saúde Mental: Uma abordagem epidemiológica. Análise Psicológica, 25(3), 439-454.

Rehm, J., \& Parry, C. (2009). Alcohol consumption and infectious diseases in South Africa. Lancet, 374(9707), 2053. doi: 10.1016/S01406736(09)62150-4

Rocha, M. L. A., Guimarães, M. B. L., \& Cunha, M. B. (2012). O processo de recuperação do uso indevido de drogas em igrejas pentecostais Assembleia de Deus. Interface- Comunicação Saúde e Educação, 16(40), 177-190.

Rodrigues, J. S. M., Ferreira, N. M. L. A., \& Caliri, M. H. L. (2013). Caracterização do apoio social percebido pela família do doente adulto com câncer. Medicina (Ribeirão Preto), 46(3), 289296.

Rodrigues, V., \& Madeira, M. (2009). Suporte social e saúde mental. Revisão da Literatura. Revista da Faculdade de Ciências da Saúde (Porto), 6, 390-399. Retrieved from http://bdigital.ufp.pt/ bitstream/10284/1293/2/390-399_FCS_06_-6. pdf 
Ronzani, T. M. (2008). Padrão de uso de álcool entre Atenção Primária à Saúde: Estudo comparativo. Revistade APS, 11(2), 163-171.

Santana, P. (Ed.). (2015). Territórios e saúde mental em tempos de crises. Portugal: Universidade de Coimbra. doi: 10.14195/978-989-26-1105-1

Santos, M. N. (2015). Solidão e saúde de idosos institucionalizados (Master thesis, Faculdade de Psicologia, Universidade de Lisboa, Portugal).

Sherbourne, C. D., \& Stewart, A. L. (1991). The MOS social support survey. Social Science \& Medicine, 32(6), 705-714. Retrieved from https://www.ncbi.nlm.nih.gov/pubmed/2035047

Silva, A. C. (2015). Levantamento do padrão de consumo de tabaco e outras drogas na gestão de cuidados em saúde em assentados de uma comunidade rural (Master thesis, Universidade Federal de Goiás, Catalão, GO, Brazil).
Sparovek, G. (2003). A qualidade dos assentamentos de reforma agrária brasileira. São Paulo, SP: Páginas \& Letras.

Zanello, V. (2016). Saúde mental, gênero e dispositivo. In M. D. B. Dimenstein, J. F. Leite, J. P. S. Macedo, \& C. M. B. Dantas (Eds.), Condições de vida e saúde mental em contextos rurais. São Paulo, SP: Intermeios.
Received: $15 / 03 / 2017$

$1^{\text {st }}$ revision: $18 / 10 / 2017$

Accepted: 19/10/2017 distribution, and reproduction in any medium, provided you give appropriate credit to the original author(s) and the source, provide a link to the Creative Commons license, and indicate if changes were made. 